\title{
Severe sepsis and cerebral toxoplasmosis in an HIV-infected late presenter patient
}

\author{
Andreea Ardeleanu ${ }^{1 *}$, Ovidiu Roşca², Maria Sandu ${ }^{3}$ \\ From The 9th Edition of the Scientific Days of the National Institute for Infectious Diseases Prof Dr Matei \\ Bals \\ Bucharest, Romania. 23-25 October 2013
}

\section{Background}

In Europe, almost a third of individuals infected with HIV do not benefit from healthcare until late in the course of their infection. It is well known that cerebral toxoplasmosis is one of the most common opportunistic neurological infections in AIDS patients, and it is typically observed in the later stages of HIV infection. Moreover, when critically ill HIV patients are admitted to ICUs the main risk factor for hospital mortality is severe sepsis.

\section{Case report}

We report the case of a 56 year-old patient admitted to our department after he had undergone a brain surgery being suspected of a brain tumor. When he was admitted to the neurosurgery department he presented with headache, speaking disorders and progressive hemiplegia. The histopathological examination revealed no malignancies in the brain tissue. Contrast enhanced CT and MRI scans of the head showed a solitary ring-enhanced mass with surrounding edema.

In our department, he presented with high fever, generalized rash, oral candidiasis and right hemiplegia. $\mathrm{He}$ tested positive for HIV and serum toxoplasma antibodies. The patient was admitted to the ICU and started anti-toxoplasmosis therapy, but developed severe sepsis with Acinetobacter baumannii. The CD4 count was 15 cells $/ \mathrm{cmm}$ and $\mathrm{VL}=756,000$ copies $/ \mathrm{mL}$.

\section{Conclusion}

Sepsis has a more severe course in HIV-positive patients being the most important risk factor for mortality in

\footnotetext{
* Correspondence: ardeleanu.andreea@gmail.com

${ }^{1}$ Department of Infectious Diseases I, Dr. Victor Babeș Clinical Hospital of

Infectious Diseases and Pneumology, Timişoara, Romania

Full list of author information is available at the end of the article
}

HIV/AIDS patients admitted to ICUs. Cerebral toxoplasmosis is still the commonest cerebral opportunistic infection in HIV-infected patients even though the incidence has declined with the use of antiretroviral therapy. It is often diagnosed as an initial presentation of HIV infection affecting short- and longer-term survival.

\section{Authors' details}

${ }^{1}$ Department of Infectious Diseases I, Dr. Victor Babeş Clinical Hospital of Infectious Diseases and Pneumology, Timişoara, Romania. ${ }^{2}$ Department of Infectious Diseases I, Victor Babeş University of Medicine and Pharmacy, Timişoara, Romania. ${ }^{3}$ City Hospital, Sânnicolau Mare, Romania.

Published: 16 December 2013

doi:10.1186/1471-2334-13-S1-P8

Cite this article as: Ardeleanu et al:: Severe sepsis and cerebral toxoplasmosis in an HIV-infected late presenter patient. BMC Infectious Diseases 2013 13(Suppl 1):P8.

Submit your next manuscript to BioMed Central and take full advantage of:

- Convenient online submission

- Thorough peer review

- No space constraints or color figure charges

- Immediate publication on acceptance

- Inclusion in PubMed, CAS, Scopus and Google Scholar

- Research which is freely available for redistribution 